\title{
Holocene Vegetation, Climate, and Carbon History on Western Kodiak Island, Alaska
}

\author{
Dorothy M. Peteet ${ }^{1,2 *}$, Jonathan E. Nichols ${ }^{2}$ and Daniel H. Mann ${ }^{3}$ \\ ${ }^{1}$ NASA Goddard Institute for Space Studies, New York, NY, United States, ${ }^{2}$ Lamont-Doherty Earth Observatory, Columbia \\ University, Palisades, NY, United States, ${ }^{3}$ Department of Geosciences, University of Alaska Fairbanks, Fairbanks, \\ AK, United States
}

At Phalarope Pond, western Kodiak Island, a multidisciplinary study using pollen and spores, macrofossils, stable isotopes, and carbon accumulation provides the Holocene vegetation and climate history following the deglaciation that began over 16,000 cal years ago (yr BP). Following a cold and dry Younger Dryas, a warm and wet early Holocene was characterized by abundant ferns in a sedge tundra environment with maximum carbon accumulation, similar to high latitude peatlands globally. About

OPEN ACCESS

Edited by:

Randel Tom Cox,

The University of Memphis,

United States

Reviewed by:

Daniel Larsen,

The University of Memphis,

United States

Chengyu Weng,

Tongji University, China

*Correspondence:

Dorothy M. Peteet

peteet@/deo.columbia.edu

Specialty section:

This article was submitted to Quaternary Science, Geomorphology and Paleoenvironment, a section of the journal Frontiers in Earth Science

Received: 30 November 2018

Accepted: 13 March 2019

Published: 09 April 2019

Citation:

Peteet DM, Nichols JE and Mann DH (2019) Holocene Vegetation, Climate, and Carbon History on Western Kodiak Island, Alaska. Front. Earth Sci. 7:61. doi: 10.3389/feart.2019.00061 8,700 cal yr BP sedge and ferns declined and climate remained warm as drier conditions prevailed, limiting carbon sequestration. The abrupt shift in $\mathrm{D} / \mathrm{H}$ isotopes of about $60 \%$ indicates a shift to cooler conditions or a more distal moisture source. Neoglaciation beginning about 3,700 cal yr BP is evident from increases in Artemisia, Empetrum and Betula, signifying cooler conditions, while Alnus declines, paralleling regional trends.

Keywords: Kodiak Island, Holocene, pollen, macrofossils, isotopes, carbon sequestration, Alaska

\section{INTRODUCTION}

Peatlands in subarctic Alaska provide a window into the history of a high latitude area that today is warming almost twice as fast as the rest of the globe (Cohen et al., 2014). Describing the Holocene history of this region and its impact on carbon sequestration becomes increasingly important as we experience this warming. While warmer temperatures foster both increased primary production and decomposition, the net carbon stored often depends on the type of vegetation (Kuiper et al., 2014) and its moisture content. While we previously identified Kodiak Island as an area that experienced a marked Younger Dryas cooling during the late-glacial (Peteet and Mann, 1994; Hadjas et al., 1998) using pollen and macrofossils, we now use these same vegetational indicators along with stable isotope to explore the vegetational, climatic, and carbon accumulation history throughout the Holocene from the same site.

\section{Study Site}

Phalarope Pond $\left(57^{\circ} \mathrm{N}, 154^{\circ} 26 \mathrm{~W}\right)$ is a kettle pond located in a recessional moraine of a glacier that flowed seaward out of Olga Bay on southwestern Kodiak Island (Figure 1). Deglaciation occurred ca. $14,700{ }^{14} \mathrm{C}$ years BP (Mann and Peteet, 1994; Peteet and Mann, 1994).

The mountainous interior of Kodiak Island results in a climatic gradient between the warmer, maritime, eastern side of the island where the town of Kodiak is located to the colder, drier, Shelikof Strait side. The town of Kodiak has an average January temperature of $0^{\circ} \mathrm{C}$ and a July 

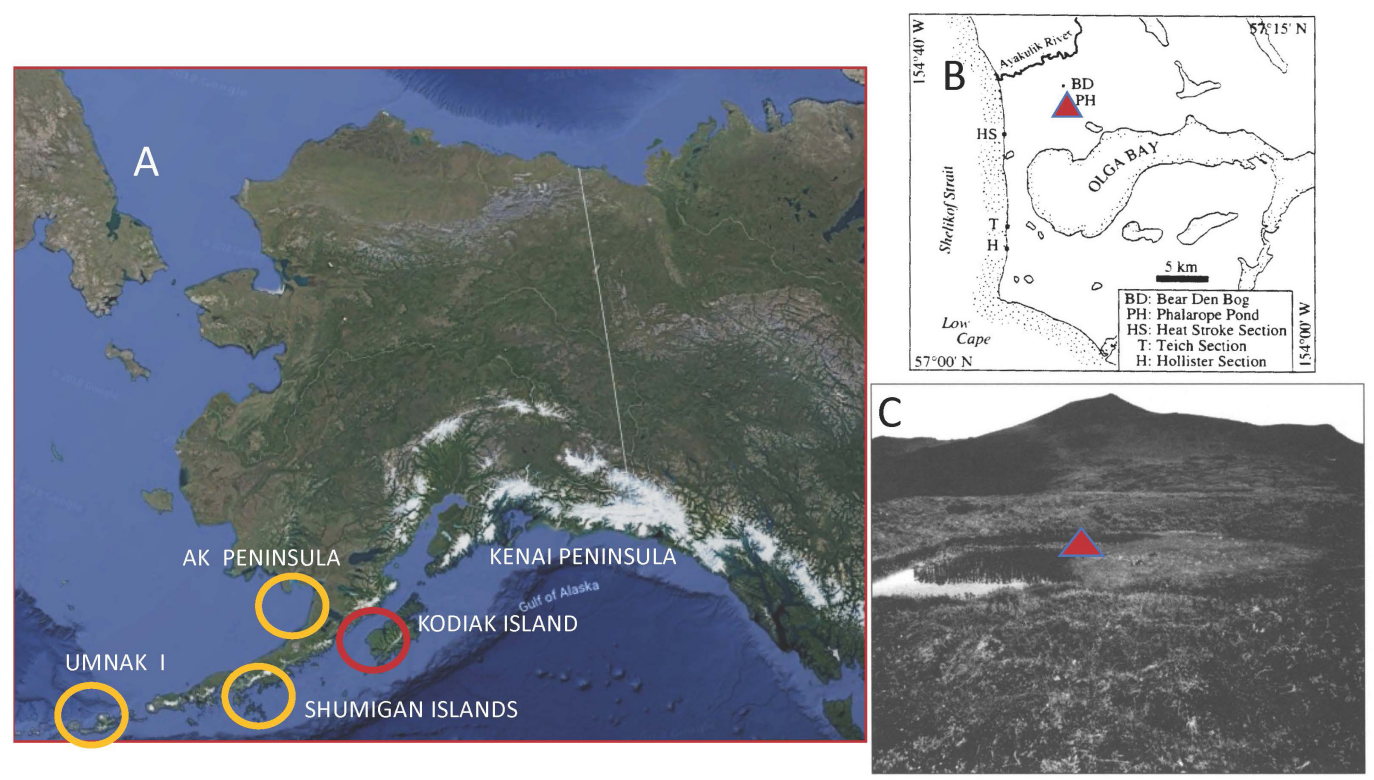

FIGURE 1 | Location of Phalarope Pond, western Kodiak Island, Alaska, with regional sites and photo of the coring site. (A) Core site location on western Kodiak and neighboring comparative sites. (B) Phalarope Pond (PH) core site north of Olga Bay, western Kodiak Island. (C) Photo of Phalarope Pond, Kodiak Island with core site (triangle)

temperature of $12.1^{\circ} \mathrm{C}$ (National Oceanic and Atmospheric Administration [NOAA], 1985). Karlstrom (1969) noted that January temperatures over $30 \mathrm{cal} \mathrm{yr} \mathrm{BP}$ are $3^{\circ} \mathrm{C}$ colder on the Shelikof Strait side of the archipelago. While Kodiak town receives $170-185 \mathrm{~cm}$ of precipitation a year (National Oceanic and Atmospheric Administration [NOAA], 1985, 2018), the Shelikof Strait side receives less than half that amount (Karlstrom, 1969). To the west, the Shumigan Islands receive a similar amount of precipitation at about $87 \mathrm{~cm}$ (Heusser, 1983), and Cold Bay on the western Alaskan Peninsula ${ }^{1}$ about $91 \mathrm{~cm}$.

Landscapes on the western side of Kodiak Island are primarily treeless, with occasional trees appearing where Picea sitchensis seeds find mineral soil, sometimes atop mountains. Moist peatlands are typical of the valley bottoms, with a dominance of sedge and moss tundra, but with shrubs of Salix, Betula, and Alnus throughout. Drier lowland hummocks are blanketed with heaths such as Empetrum nigrum, Arctostaphylos uvaursi, Vaccinium vitis-idaea, V. uliginosum, as well as Betula nana. Wetland habitats such as border Phalarope Pond contain abundant Sphagnum and Carex together with Ledum palustre, V. vitis-idaea, Rubus chamaemorus, and Drosera rotundifolia. Emergent/quatic plants include Menyanthes trifoliata, Hippuris vulgaris, and Nuphar polysepalum. Blanketing moist slopes above the peatlands are meadows of abundant herbs such as Veratrum viride, Sanguisorba stipulata, Polemonium acutiflorum, and Epilobium angustifolium, while drier slopes include Calamagrostis canadensis subsp. Langsdorffi and Heracleum lanatum and ferns such as Dryopteris dilatata and Athyrium filix-femina. At the boundary

${ }^{1}$ http://www.cold-bay.climatemps.com/ of meadows and alpine heath, Alnus shrubs and Rubus spectabilis occur.

\section{MATERIALS AND METHODS}

Phalarope Pond (Figure 1), at $30 \mathrm{~m}$ elevation, is a small circular kettle from which we retrieved an 8.2-m core at the center of the pond, along the edge of an encroaching bog mat which extends halfway across the pond. A modified Livingstone piston corer (Wright et al., 1984) was used for sediment extraction. Cores were extruded in the field, wrapped in plastic film and aluminum foil, and stored in the refrigerated repository at LDEO. The lowest $4 \mathrm{~m}$ of sediment are comprised of silty organics, ending in gravel at the base. The core was sampled for pollen and spores at $5-$ or $10-\mathrm{cm}$ intervals. Samples were processed using $2 \mathrm{ml}$ of sediment, following the procedures of Heusser and Stock (1984). Lycopodium clavatum tablets were added to calculate pollen concentrations, and processing included use of $\mathrm{KOH}, \mathrm{HCL}$ and HF, 150 and 7 micron screening, as well as acetolysis, alcohol dehydration, and silicone oil mounts. At least 300 pollen grains were counted for each sample, and spores tallied in addition. Pollen slides were examined at $400 \times$, and identified with a coastal Alaskan reference collection (i.e., Heusser and Peteet, 1987). Percentage of spores is based upon the sum of pollen and spores. Nomenclature follows Hulten (1968), and data were plotted using Tiliagraph (Grimm, 1992).

Soluble lipids were extracted from freeze-dried peat samples by three successive rounds of ultrasonic agitation in hexane. The three rinses were combined for the total lipid extract (TLE). TLE was separated by silica gel flash column chromatography into three fractions: hydrocarbons are eluted with hexane; ketones, 
esters, and aromatic compounds with dichloromethane; and polar compounds with methanol. Hydrocarbons were quantified prior to hydrogen isotope analysis by gas chromatographyflame ionization detection (GC-FID). Hydrogen isotope ratios of individual $n$-alkanes were determined by continuous flow isotope ratio mass spectrometry. Eluent from a gas chromatograph (Thermo Trace GC) passes through a pyrolysis reactor (Thermo GC IsoLink) where organic compounds are converted to $\mathrm{H}_{2}$ gas, which then is passed to the IRMS (Thermo Delta V) via a continuous flow device (Nichols et al., 2014a).

Hydrogen isotope ratios of peatland water is calculated from the $\delta \mathrm{D}$ of $\mathrm{C}_{29} n$-alkane (n-nonacosane) using an empirical apparent enrichment factor. For each sample an elw is chosen based on the macrofossil stratigraphy. In parts of the stratigraphy where vascular vegetation is dominated by sedges, a median elw for monocots is used, and where vascular vegetation of the peatland is dominated by ericads, a median elw for dicots is used. Enrichments for these vegetation types are from published literature (Sachse et al., 2012). Uncertainty around these enrichment factors (about $\pm 30 \% 0$ ) as well as analytical uncertainty $( \pm 2 \% 0$ are propagated through calculations of peatland water $\delta \mathrm{D})$. We only interpret changes in $\delta \mathrm{D}$ of peatland water that exceed $75 \%$ confidence based on this propagated uncertainty (Nichols et al., 2014a,b).

Percent weight loss on ignition (LOI) followed Dean (1974), and after drying, samples were burned at $550 \mathrm{C}$ for $2 \mathrm{~h}$. LOI and bulk density measurements were multiplied to calculate ash-free bulk density. Carbon content was calculated from the ash-free bulk density by multiplying by.423 in Sphagnum peat and 0.511 in sedge peat (Loisel et al., 2014).

Samples were screened for macrofossils at $5 \mathrm{~cm}$ intervals using screens of 0.5 and $0.1 \mathrm{~mm}$, picked in water at a magnification of 20-60×, and identified using the macrofossil collection at LDEO. All samples are stored in the LDEO refrigerated repository in water. Identified samples for AMS dating were sent to the National Ocean Science AMS Facility (NOSAMS, Woods Hole).

Radiocarbon ages on identified plant macrofossils are presented in Table 1. The ${ }^{14} \mathrm{C}$ ages were calibrated using CALIB $7.1 \mathrm{html}$ (Stuiver et al., 2019). We used the "Bacon" Bayesian agedepth modeling tool to estimate the ages of sediment samples (Blaauw and Christen, 2011). All radiocarbon dates fell within the 95\% confidence intervals around the resulting age model. Input and "priors" files are available here as a supplement. Ages are presented in calibrated years, years BP (Before Present,; 0 year $\mathrm{BP}=1950 \mathrm{AD})$, and uncertainties are shown at the 95\% (2- sigma) confidence level. Pollen and spore percentage diagrams as well as the macrofossil diagram were drafted using Tilia (Grimm, 1992). Pollen and macrofossil data are stored in the Neotoma database.

\section{RESULTS}

The three tephras that define the earliest late-glacial- (purple), the mid- Younger Dryas white tephra, and the early Holocene gray tephra $(10,200 \mathrm{cal}$ yr BP) are described along with the chronology, pollen and spores, and macrofossils in Peteet and Mann (1994). We refer to that discussion for the late-glacial,
TABLE 1 | AMS radiocarbon depths, macrofossil identification, and ${ }^{14} \mathrm{C}$ ages.

\begin{tabular}{|c|c|c|c|c|}
\hline Lab number & $\begin{array}{l}\text { Depth } \\
\text { (cm) }\end{array}$ & Macrofossil & $\begin{array}{l}\text { C-14 age } \\
\text { (year BP) }\end{array}$ & Age error \\
\hline OS-83647 & 76.5 & 2 Nuphar seeds & 1,390 & 20 \\
\hline OS-83648 & 76.5 & $\begin{array}{l}\text { Vaccinium stem, } \\
\text { Empetrum seed }\end{array}$ & 1,280 & 15 \\
\hline OS-83921 & 106.5 & 3 Empetrum Ivs & 2,630 & 55 \\
\hline OS-83927 & 121.5 & $\begin{array}{l}\text { Empetrum leaf, } \\
\text { Polytrichum moss }\end{array}$ & 3,560 & 45 \\
\hline OS-87759 & 152 & Woody fragments & 2,800 & 45 \\
\hline OS-87494 & 154.5 & Woody fragments & 2,700 & 45 \\
\hline OS-87459 & 202.5 & Isoetes spores & 5,700 & 40 \\
\hline OS-83646 & 236.5 & $\begin{array}{l}\text { Empetrum seed } \\
\text { and woody frag }\end{array}$ & 2,500 & 30 \\
\hline OS-87762 & 277.5 & Carex seed & 7,470 & 100 \\
\hline OS-84809 & 322.5 & $\begin{array}{l}1 \text { Carex seed, } 3 \\
\text { Eriophorum seeds }\end{array}$ & 8,120 & 410 \\
\hline OS-84810 & 412.5 & Wood & 8,830 & 470 \\
\hline \multirow[t]{2}{*}{ OS-87753 } & 432.5 & $\begin{array}{l}\text { Purified leaf-wax } \\
\text { n-alkanes }\end{array}$ & 9,760 & 50 \\
\hline & 500 & Gray tephra & & \\
\hline
\end{tabular}

but will here begin descriptions of the core with the earliest Holocene, which includes many cryptic tephras. As Heusser (1990) noted, tephra can play a role in shaping vegetational communities if edaphic conditions are changed due to drainage shifts or additional nutrients. Because the tephras are not clearly visible in the Holocene peat, we cannot attribute any vegetational shifts to tephra, but they may have played a role.

\section{Chronology, Figure 2 and Table 1}

Identified macrofossils from 12 samples were pre-treated with an acid-alkali-acid chemical digestion prior to combustion, graphitization, and measurement by accelerator mass spectrometry. The age-depth model based on AMS dates (Table 1) is presented in Figure 2, which shows highest sedimentation rates in the lower part of the core and a shift to lower rates at about $2 \mathrm{~m}$ from the surface, followed by higher rates again about $1.5 \mathrm{~m}$ when the site shifts from a shallow pond to a peatland as indicated in the lithology and LOI results.

\section{LOI, Sedimentation Rate, and Carbon Accumulation Rate, $\mathrm{g} / \mathrm{m}^{2} /$ Year (CAR), Figures 3-5}

Loss on ignition $(<10 \%)$ and sedimentation rates were low during the late glacial $(0.3 \mathrm{~mm} /$ year, Figure 3$)$, while CAR was relatively high (Figure 5), linked to the relatively warm, moist Bölling-Alleröd period prior to the cold and dry Younger Dryas (Peteet and Mann, 1994). Above the gray tephra, pond sediment is comprised of low organic content, increasing from around $2 \%$ at the level of the gray tephra at $5 \mathrm{~m}$, to close to $10 \%$ between 5 and $4 \mathrm{~m}$ depth, between $10 \mathrm{ka}$ and 8,500 cal yr BP. Highest sedimentation rates occurred during the earliest Holocene when they reached $1 \mathrm{~mm} /$ year. The carbon accumulation rate averaged about $10 \mathrm{~g} / \mathrm{m}^{2} / \mathrm{a}$ until about $10 \mathrm{cal} \mathrm{kyr}$ when it increased to 


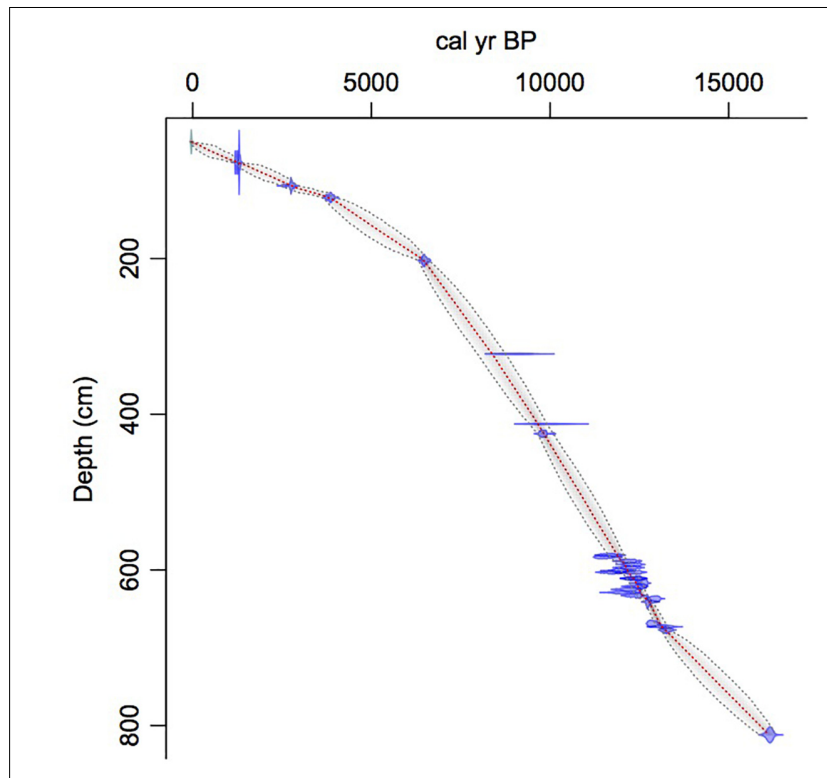

FIGURE 2 | Age-depth model. Red line indicates median age. Dotted lines indicate 95\% confidence interval around the median age. Blue areas indicate calibration ranges for individual radiocarbon dates.

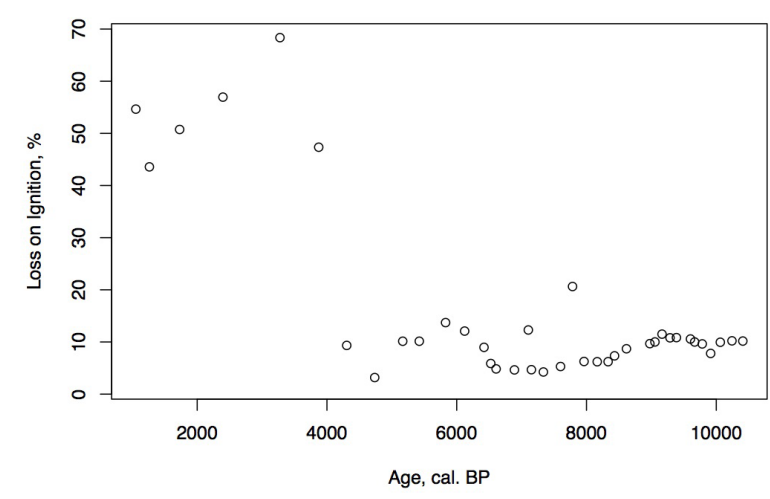

FIGURE 3 | Holocene age-depth plot and LOI for the Phalarope Pond core.

$20 \mathrm{~g} / \mathrm{m}^{2} / \mathrm{a}$, a maximum for the entire core. Above a depth of $350 \mathrm{~cm}(8,700 \mathrm{cal}$ yr BP) the LOI, sedimentation rate, and CAR decline, with the LOI averaging less than $10 \%$, the sedimentation rate declining from 0.6 to $0.2 \mathrm{~mm} /$ year, and the CAR fluctuating at $<10 \mathrm{~g} / \mathrm{m}^{2} / \mathrm{yr}$. Above $150 \mathrm{~cm}(4,775 \mathrm{cal} \mathrm{yr} \mathrm{BP})$, LOI increases and averages close to $50 \%$, sedimentation rate rises to between 0.2 and $0.6 \mathrm{~mm} /$ year, and CAR increase again to almost $15 \mathrm{~g} / \mathrm{m}^{2} /$ year in the uppermost peat near the surface of the floating mat of peat.

\section{Pollen, Spores, and Macrofossil Analysis Groupings and Zonation (Figures 6, 7)}

Modern pollen-vegetational relationships were described by Peteet and Mann (1994) for this area of western Kodiak Island. We can use these relationships to interpret the vegetational history of the Holocene, just as we did for the late-glacial.

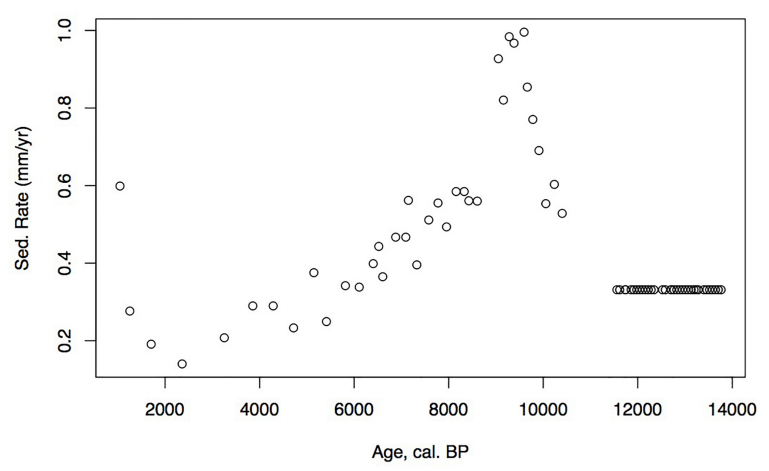

FIGURE 4 | Holocene age-depth plot and sedimentation rates ( $\mathrm{mm} /$ year) for Phalarope Pond, Kodiak, AK.

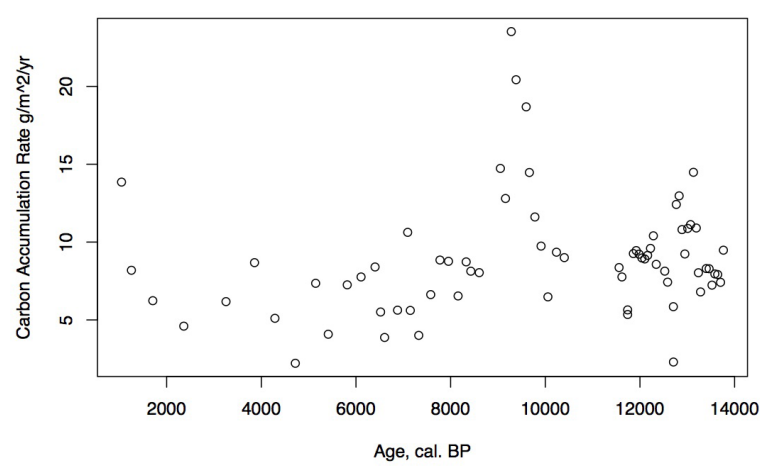

FIGURE 5 | Holocene carbon accumulation rate (CAR) in $\mathrm{g} / \mathrm{m}^{2} /$ year for Phalarope Pond, AK.

\section{Zone P-4, (11,500-8,700 ka, 550-350 cm Depth)}

Zone P-4 encompasses the earliest Holocene zone, and the peat brackets the $70 \mathrm{~cm}$ of thick gray tephra. Polypodiaceae reach maximum values in this zone (80\%), and Cyperaceae and Poaceae reach $40 \%$, while Ericales remain at 10\%, Empetrum leaves are sometimes present, and Apiaceae, Sanguisorba, and Asteraceae are quite visible in the record. Sanguisorba and Fritillaria are consistently present, while Betula and Alnus appear in very low percentages. Isoetes microspores and macrospores gradually increases upward, indicative of a wet environment, along with the fluctuating presence of other aquatic indicators such as Nuphar and Naias, bryozoan statoblasts, and cladoceran ephippia. Lenticular Carex achenes appear along with some Empetrum leaves, Viola seeds, and Vaccinium uliginosum and Rubus arcticus seeds. Sphagnum leaves are present throughout this zone, along with three other bryophytes.

\section{Zone P-5, (8,700-7,600 ka, 300-275 cm Depth)}

Ericales remain at about $10 \%$, while Cyperaceae decline to as low as $25 \%$, and then increase again at the top of the zone. Poaceae 


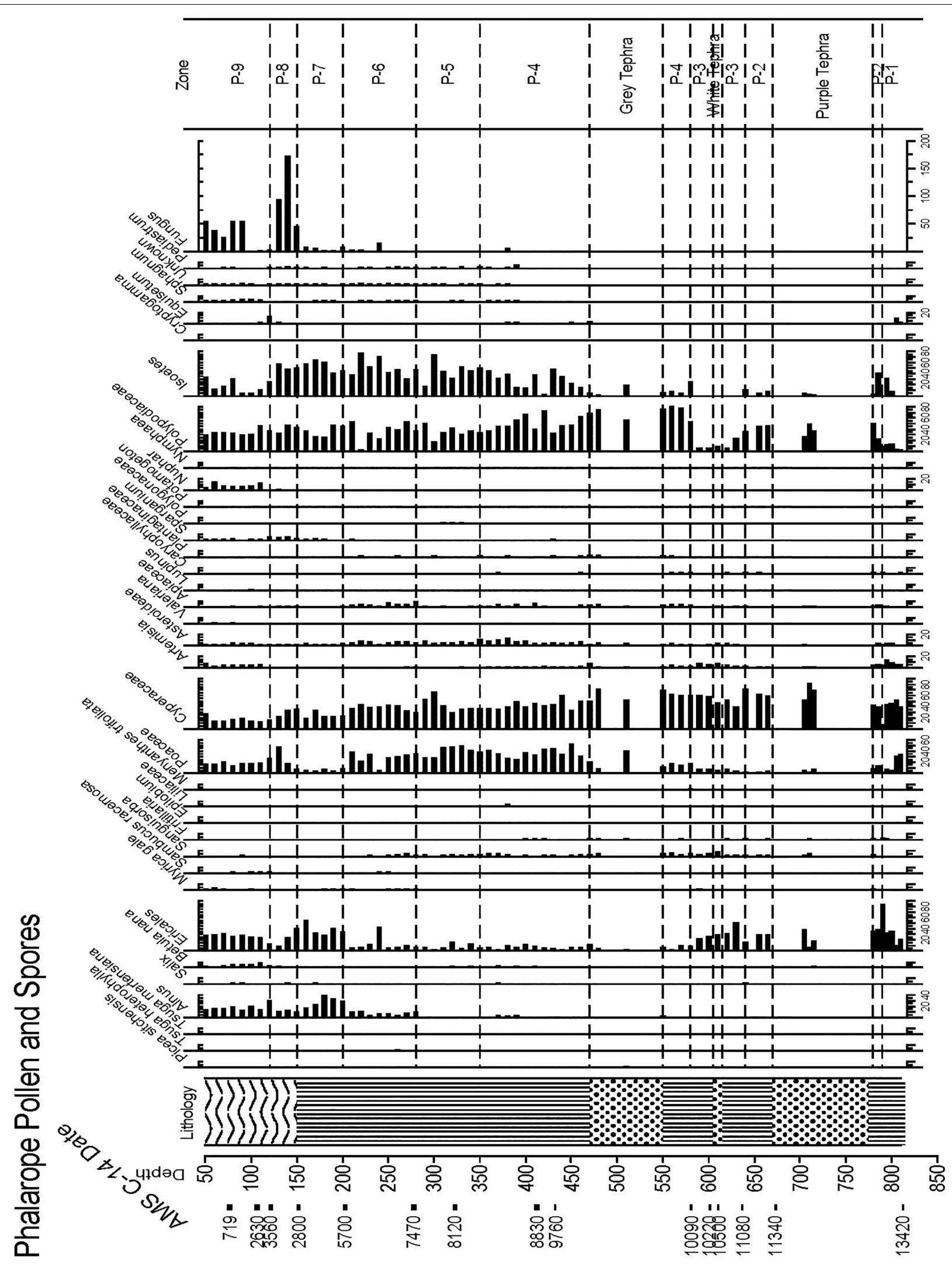

FIGURE 6 | Pollen and spore percentage data from Phalarope Pond, Kodiak Island. 





remain close to $40 \%$, while ferns decline to below $40 \%$, and Isoetes spores continue to increase. A decline in the Apiaceae, disappearance of Alnus, Nuphar and cladoceran ephippia, as well as bryozoan statoblasts is notable. Sanguisorba is present, and Eriophorum seeds appear in this zone. A marked decline in Sphagnum is visible, and an increase in Polytrichum in one sample is paralleled by charcoal.

\section{Zone P-6, (7,600-6,500 ka, 275-200 cm Depth)}

Alnus consistently reaches $10 \%$, Myrica gale is present, Ericales remain at the same value generally, and Poaceae and Cyperaceae decline to between 30 and $40 \%$. Apiaceae reach maximum values, Sanguisorba remains throughout, Asteroideae are still abundant, Polypodiaceae again increase, and Isoetes microspores reach maximum values while Sphagnum declines but is still present throughout. Selaginella selaginoides macrospores make a first appearance, and cladoceran ephippia are present.

\section{Zone P-7, (6,500-4,800 ka, 200-150 cm Depth)}

While Poaceae decline markedly in this zone to $10 \%$, Ericales increase from 10 to greater than $40 \%$. Alnus rises from $10-$ $30 \%$. Cyperaceae decline, while Polypodiaceae fluctuate between 20 and $40 \%$, and Isoetes microspores remain abundant while Isoetes macrospores decline to 0 . The zone is almost devoid of macrofossils, and more pebbles are present in this zone than previous zones. Salix increases while Apiaceae disappear.

\section{Zone P-8, (4,800-3,700 ka, 150-120 cm Depth)}

Betula increase, Ericales decline while Poaceae, Cyperaceae, and Sparganium increase, and fungal spores become abundant. The zone is almost devoid of macrofossils, with the exception of minimal cladoceran ephippia, 1 Empetrum leaf, 1 Naias seed, and minimal Sphagnum, and Polytrichum strictum at the top of the zone, along with many fungal spores.

\section{Zone P-9, (3,700- Present, 120 - Core Surface, With $50 \mathrm{~cm}$ Water Depth)}

Especially distinctive in this zone are Betula and Artemisia, which reach their maximum values here, along with $S$. selaginoides macrospores. Empetrum seeds and leaves are consistently present along with Nuphar pollen and seeds, while Alnus declines and both Poaceae and Cyperaceae decline. Fungal spores are also prominent, and Sphagnum leaves appear.

\section{DISCUSSION}

\section{Early Holocene (11,500-8,700 ka)}

The low organic matter but presence of shallow aquatic indicators such as Nuphar polysepalum, Naias, bryozoan statoblasts, and cladoceran ephippia, along with the increasing presence of Isoetes, indicate a shallow pond environment. The extremely high percentages of fern spores along with high percentages

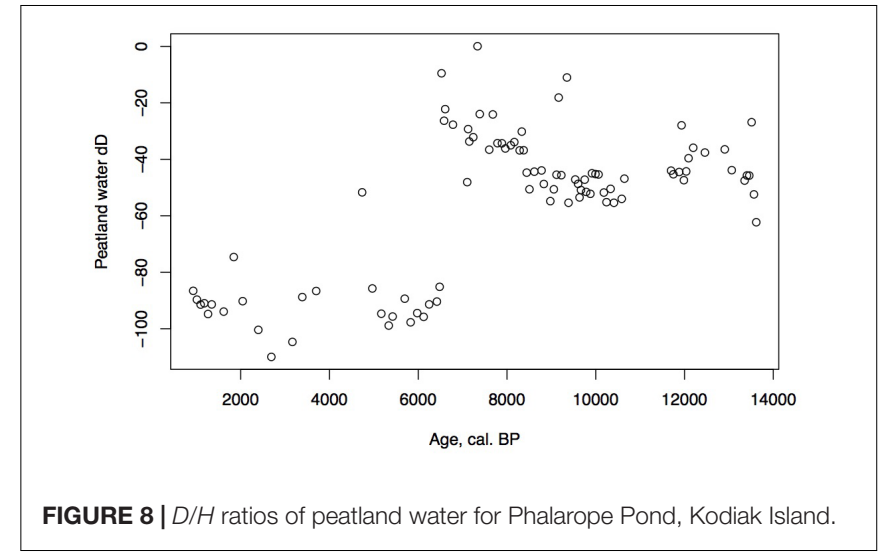

of sedge and grass, Sphagnum, and a diversity of moss species indicate this period was relatively warm and moist. Supporting this inference is the presence of Fritillaria, along with Apiaceae, Sanguisorba, and Asteroideae. CAR reaches its highest rates for the entire core $\left(20 \mathrm{~g} / \mathrm{m}^{2} /\right.$ year, Figure 5), a rate similar or greater than at coastal Alaskan sits such as the Kenai Peninsula (Jones and $\mathrm{Yu}, 2010$ ) where this interval is recognized as the Holocene thermal maximum (HTM). Similarly, the highest CAR from Corser Bog, near Cordova Alaska, occurs during this same early Holocene interval (Peteet et al., 2016), although rates there are significantly higher. The $\mathrm{D} / \mathrm{H}$ ratios of peatland water are enriched relative to the rest of the record, (Figure 8) suggesting precipitation is derived from local air masses originating in the North Pacific. Alternatively, enriched isotopes of precipitation could indicate increased warm season precipitation. Either interpretation would support moist growing season conditions during this interval, favorable for more rapid carbon accumulation. West of Kodiak, a welldated site on Adak Island in the Aleutians shows a very high accumulation rate during the early Holocene, similar to Phalarope (Noguchi et al., 2018). Rapid peatland expansion and highest $\mathrm{C}$ accumulation during this interval is linked to early Holocene peatland carbon storage throughout the Subarctic (Loisel et al., 2014).

Interestingly, the very low percentage of Alnus in this interval, less than $5 \%$, is in contrast to sites on eastern Kodiak during the early Holocene where it reaches up to $50 \%$ of the pollen sum (Heusser, 1960). At the village site of Karluk, north of our site on the western edge of Kodiak Island, both Heusser (1960) and Nelson and Jordon (1988) retrieved cores dating back to the mid-Holocene, and both show a large decline in Alnus from the mid-Holocene toward the present, similar to this pollen record.

\section{Early Mid-Holocene (8,700-7,600 ka)}

The decline in fern spores as well as Sphagnum and Cyperaceae, with the increase in grasses suggests a slightly warm, drier environment, but one that is still very moist. As the sedimentation rate declines, so does the CAR, to an average less than $10 \mathrm{~g} / \mathrm{m}^{2} / \mathrm{a}$. The shallow lake sediment with Isoetes includes the first evidence of fire on the landscape. 


\section{Mid-Holocene (7,600-6,500 ka)}

Alnus appears to expand its range into southwestern Kodiak Island in response to early Holocene warmth. The vegetation suggests a climate that was warm and moist until the close of the zone. Specifically, Apiaceae pollen reach maximal values, fern spores remain abundant, and Sanguisorba and S. selaginoides both moist peatland indicators - are present. At the close of this zone ca. $6,500 \mathrm{cal} \mathrm{yr} \mathrm{BP}, \mathrm{D} / \mathrm{H}$ ratios of peatland water show a large shift of about $60 \%$ toward more depleted values (Figure 8), Several climatic factors could contribute to this dramatic depletion. Precipitation source could have shifted away from the warm, nearby North Pacific to higher-latitude, colder, or more distal moisture sources, such as from the Bering Sea (Lachniet et al., 2016), which would have less precipitable moisture. Also, a shift in seasonality of precipitation resulting in more cold season precipitation and less warm season could produce a similar shift (Nichols et al., 2009). Any of these influences, however, would result in less available moisture for peatland vegetation, resulting in the lowered rates of carbon accumulation we observe in the subsequent interval.

\section{Late Mid-Holocene (6,500-3,700 ka)}

The continued decline of Apiaceae, Cyperaceae, fern spores, and Sphagnum spores, with some fluctuation along with a declining sedimentation rate and CAR all suggest further drying of the landscape. Alnus, which was rare earlier in the Holocene, is consistently present, suggesting migration into the area from the eastern part of the island (Heusser, 1960). Alnus pollen reached $50 \%$ at Karluk to the north at around 4,500 cal yr BP. Further west, Alnus is present in the Shumigan Islands in the midHolocene (Heusser, 1983). Sanguisorba, a moist peatland herb, disappears. The presence of Artemisia and Ericales (probably Empetrum expansion) suggests a drier climate. Fungal spores reach their peak, also suggestive of drier conditions. The $\mathrm{D} / \mathrm{H}$ ratio of peatland water (Figure 8) remains very depleted generally during this interval relative to the Early Holocene, suggesting the prevalence of air masses coming from colder and/or more distal regions or decreased growing season precipitation in favor of winter. Carbon accumulation continues to decline to less than $10 \mathrm{~g} / \mathrm{m}^{2} /$ year (Figure 5).

\section{Late Holocene (3,700 to Present)}

The shallow pond begins to be covered by a mat of peat as indicated by the increase in Sphagnum spores and the decline in Isoetes. LOI, sedimentation rate, and carbon accumulation rate increase. At the same time, Nuphar pollen and seeds, Sparganium pollen, and cladoceran ephippia indicate the presence of shallow pools of water in the peatland. However, the sustained presence of Artemisia and Betula along with the decline of Alnus suggest colder and possibly drier conditions, as does the fungal presence. Carbon accumulation begins to increase as Sphagnum increases, until it ranges between 10 and $15 \mathrm{~g} / \mathrm{m}^{2} /$ year. The Alnus decline in the late Holocene is paralleled in Heusser's (1960) records from both sides of Kodiak Island, as is the general increase in Ericales and Sphagnum. Nelson and Jordon's (1988) Karluk site similarly shows an increase in Artemisia in the late Holocene, with a decline in fern spores. The $\mathrm{D} / \mathrm{H}$ ratios of peatland water continue to show very depleted values (Figure 8). As the North Pacific high presumably moves eastward, drier, isotopically depleted air masses derived from the Bering Sea region may have been brought to the site. In contrast to locations bordering the eastern Gulf of Alaska (Heusser, 1960; Heusser et al., 1985; Peteet, 1986; Ager et al., 2010; Peteet et al., 2016) where colder, wetter climate occurred during the late Holocene, at Phalarope Pond climate seems to have been cooler, but the available moisture is difficult to discern.

\begin{tabular}{|l|l|l|l|l|l|l|}
\hline $\begin{array}{l}\text { Ages } \\
\text { ka }\end{array}$ & $\begin{array}{l}\text { E.Aleutian } \\
\text { Islands } \\
\text { Umnak }\end{array}$ & $\begin{array}{l}\text { Alaska } \\
\text { Peninsula } \\
\text { Kinzarof } \\
\text { Marsh }^{2}\end{array}$ & $\begin{array}{l}\text { Alaska } \\
\text { Peninsula } \\
\text { Cape } \\
\text { Aliaksin }\end{array}$ & $\begin{array}{l}\text { Shumagin } \\
\text { Islands } \\
\text { Unga }^{3}\end{array}$ & $\begin{array}{l}\text { W.Kodiak } \\
\text { Island } \\
\text { (this paper })\end{array}$ & Climate \\
\hline $\mathbf{3 7 0 0}$ & Poa-Cyp & $\begin{array}{l}\text { Cyp-Emp- } \\
\text { Al-Cyp- } \\
\text { Poa }\end{array}$ & $\begin{array}{l}\text { Cyp-Bet- } \\
\text { Emp }\end{array}$ & Bet-Al-Cyp & $\begin{array}{l}\text { Emp-Cyp- } \\
\text { Poa-Bet- } \\
\text { Art }\end{array}$ & Cooler \\
\hline & $\begin{array}{l}\text { Sal-Poa- } \\
\text { Cyp }\end{array}$ & $\begin{array}{l}\text { Poa-Poly- } \\
\text { Emp }\end{array}$ & $\begin{array}{l}\text { Bet-Emp } \\
\text { Cyp-Bet- } \\
\text { Emp }\end{array}$ & $\begin{array}{l}\text { Cyp } \\
\text { Emp-Art- } \\
\text { Poa }\end{array}$ & $\begin{array}{l}\text { Cyp-Poa } \\
\text { Sal }\end{array}$ & Drier \\
$\mathbf{6 5 0 0}$ & Cyp-Api- & & $\begin{array}{l}\text { Cyp-Poa- } \\
\text { Emp }\end{array}$ & $\begin{array}{l}\text { Bet-Emp- } \\
\text { Poa } \\
\text { Poa-Sal-Art }\end{array}$ & $\begin{array}{l}\text { Poly-Cyp- } \\
\text { Poa }\end{array}$ & Warm, wet \\
\hline $\mathbf{1 1 , 5 0 0}$ & Poa-Poly & & & & Cyp-Emp & Cold \\
\hline & & & & & & \\
\hline & & & & &
\end{tabular}

FIGURE 9 | Regional chart of pollen and spore dominance on Kodiak Island compared with sites in the Aleutians, the Shumigan Islands, and the western Alaskan Peninsula, along with inferred climate. Al, Alnus; Ap, Apiaceae; Art, Artemisia; Aster, Asteraceae; Bet, Betula; Cyp, Cyperaceae; Emp, Empetrum; Poa, Poaceae; Poly, Polypodiaceae; Sal, Salicaceae. Heusser, 1973; Heusser, 1983; Jordan and Krumhardt, 2003. 


\section{CONCLUSIONS IN A REGIONAL CONTEXT}

Early Holocene (11.5-8,700 cal yr BP) warmth and moisture characterize western Kodiak Island, with maximum carbon sequestration reaching $\left(20 \mathrm{~g} / \mathrm{m}^{2} /\right.$ year) (Figures 5, 9). This pattern of increased early Holocene CAR is similar to peatlands in the central and eastern Gulf of Alaska (Jones and Yu, 2010; Peteet et al., 2016) which have much higher rates of $\mathrm{C}$ accumulation (up to $50 \mathrm{~g} / \mathrm{m}^{2} /$ year) as well as high latitude peatlands globally (Loisel et al., 2014). Yet while western Kodiak Island has a dry and cool climate compared with peatlands surrounding the Gulf of Alaska to the east, carbon storage does fluctuate in response to climate forcing throughout the Holocene. A drier, more evaporative climate is present in the mid-Holocene $(8,700-3,700$ cal yr BP) when low LOI, low sedimentation rates, and increases in the abundances of fungal spore are concurrent with low rates of carbon accumulation. An abrupt depletion in $\mathrm{D} / \mathrm{H}$ ratio of peatland water at ca. 6,500 cal yr BP suggests a commensurately abrupt shift to a cooler or more distal moisture source. Westward on Umnak Island and in the Shumigans (Figures 1, 9), warmer conditions also prevailed (Heusser, 1973; Heusser, 1983). On the western Alaskan Peninsula, Jordan and Krumhardt (2003) find warmer conditions with active dunes. Neoglaciation (3,500 cal yr BP - present) followed, as seen in many other pollen records (Heusser, 1960, 1983; Heusser et al., 1985; Peteet, 1986, 1991; Jones et al., 2009; Ager et al., 2010; Peteet et al., 2016) along with glacial advances (Barclay et al., 2009 , 2013) resulting in a cooler climate with increasing

\section{REFERENCES}

Ager, T. A, Carrara, P. E., McGeehin, J. P. (2010). Ecosystem development in the Girdwood area, south-central Alaska, following late Wisconsin glaciation. Can. J. Earth Sci. 47, 971-985. doi: 10.1139/E10-020

Barclay, D. J., Wiles, G. C., and Calkin, P. E. (2009). Holocene glacier fluctuations in alaska. Quat. Sci. Rev. 28, 2034-2048. doi: 10.1016/j.quascirev.2009. 01.016

Barclay, D. J., Yager, E. M., Graves, J., Klozko, M., and Calkin, P. (2013). Late holocene glacial history of the copper river delta, coastal south-central alaska, and controls on valley glacier fluctuations. Quat. Sci. Rev. 81, 74-89. doi: 10. 1016/j.quascirev.2013.10.001

Blaauw, M., and Christen, J. A. (2011). Flexible paleoclimate age-depth models using an autoregressive gamma process. Bayesian Anal. 6, 457-474.

Cohen, J., Screen, J. A., Furtado, J. C., Barlow, M., Whittleston, D., Coumou, D., et al. (2014). Recent arctic amplification and extreme mid-latitude weather. Nat. Geosci. 7, 627-637. doi: 10.1038/ngeo2234

Dean, W. Jr. (1974). Determination of carbonate and organic matter in calcareous sediments and sedimentary rocks by loss on ignition: comparison with other methods. J. Sediment. Petrol. 44, 242-248.

Grimm, E. (1992). Tilia and Tilia-graph Software. Version 2.0. Springfield: Illinois State University.

Hadjas, I., Bonani, G., Boden, P., Peteet, D., and Mann, D. (1998). Cold reversal on kodiak island correlated with european YD using variations of the atmospheric 14C/12C. Geology 26, 1047-1050. doi: 10.1130/0091-7613(1998)026<1047: CROKIA $>2.3 . \mathrm{CO} ; 2$

Heusser, C. J. (1960). Late Pleistocene Environments of North Pacific North America. New York, NY: American Geographical Society.
Artemisia and Betula, declines in Alnus, increased Sphagnum and $S$. selaginoides and a rise in carbon accumulation to between 10 and $15 \mathrm{~g} / \mathrm{m}^{2} /$ year. A late-Holocene shift in sea surface temperatures indicative of cooling is also noted by Sabin and Pisias (1996) with intensification of the Aleutian Low. As a warming climate continues, it is clear that the availability of moisture will determine whether peatlands on western Kodiak Island and throughout the northern high latitudes will store more carbon or less.

\section{AUTHOR CONTRIBUTIONS}

DP and DM participated in field work, while all authors generated data, conducted analyses, and produced figures. DP, JN, and DM wrote and edited the text.

\section{FUNDING}

This study was funded by NASA/GISS, NSF ARC \#1022979 and the Climate Center of the Lamont-Doherty Earth Observatory.

\section{ACKNOWLEDGMENTS}

Many thanks again to Jill Bubier, Brett Engstrom, Fred Haering, Lawrence Plug, Michael Shephard, and George Stone III for robust field assistance. Personnel of the Kodiak Wildlife Refuge donated advice and support, and R. Ruoss provided logistical aid in air support.

Heusser, C. J. (1973). Postglacial vegetation on Umnak Island, Aleutian Islands, Alaska. Rev. Palaeobot. Palynol. 15, 277-285. doi: 10.1016/0034-6667(73) 90033-X

Heusser, C. J. (1983). Pollen diagrams from the Shumagin Islands and adjacent Alaska Peninsula, southwestern Alaska. Boreas 12, 279-295. doi: 10.1111/j. 1502-3885.1983.tb00322.x

Heusser, C. J. (1990). Late Quaternary vegetation of the Aleutian Islands, southwestern Alaska. Can. J. Bot. 68, 1320-1326. doi: 10.1139/b90-168

Heusser, C. J., Heusser, L., and Peteet, D. (1985). Late Quaternary climate changes on the American North Pacific coast. Nature 315, 485-487. doi: 10.1038/ $315485 \mathrm{a} 0$

Heusser, C. J., and Peteet, D. M. (1987). Spores of Lycopodium and Selaginella of the American North Pacific Region. Can. J. Bot. 66, 508-525. doi: 10.1139/b88-074

Heusser, L. E., and Stock, C. E. (1984). Preparation techniques for concentrating pollen from marine sediments and other sediments with low pollen density. Palynology 8, 225-227. doi: 10.1080/01916122.1984.9989279

Hulten, E. (1968). Flora of Alaska, and the Yukon. Lund: Gleerup.

Jones, M., Peteet, D., Kurdya, D., and Guilderson, T. (2009). A 14,000-year peatland record from the Kenai, Alaska: vegetation history and implications for atmospheric circulation patterns. Quatern. Res. 72, 207-217. doi: 10.1016/ j.yqres.2009.04.002

Jones, M. and Yu, Z. (2010). Rapid deglacial and early Holocene expansion of peatlands in Alaska. Proc. Natl. Acad. Sci. 107, 7347-7352. doi: 10.1073/pnas. 0911387107

Jordan, J. W., and Krumhardt, A. (2003). Postglacial climate and vegetation of the western Alaskan Peninsula. Alaska J. Anthropol. 1, 16-33.

Karlstrom, T. N. V. (1969). "Geological investigation of the Kodiak Island Refugium," in The Kodiak Island Refugium: Its Geology, Flora, Fauna, and History, eds T. N. V. Karlstrom and G. E. Ball (Whitby: Ryerson Press), 20-54. 
Kuiper, J. J., Mooij, W. M., Bragazza, L., and Robroek, B. (2014). Plant functional types define magnitude of drought response in peatland CO2 exchange. Ecology 95, 123-131. doi: 10.1890/13-0270.1

Lachniet, M. S., Lawson, D. E., Stephen, H., Sloat, A. R., and Patterson, W. P. (2016). Isoscapes of $\delta 18 \mathrm{O}$ and $\delta 2 \mathrm{H}$ reveal climatic forcings on Alaska and Yukon precipitation. Water Res. Res. 52, 6575-6586. doi: 10.2193/2007-2115

Loisel, J., Yu, Z., Beilman, D. W., Camill, B., Alm, J., Amesbury, M. J., et al. (2014). Northern peatland database and synthesis. Holocene 24:1028. doi: 10 . 1177/0959683614538073

Mann, D. H., and Peteet, D. M. (1994). Extent and timing of the last glacial maximum in southwestern Alaska. Quatern. Res. 42, 136-148. doi: 10.1006/ qres.1994.1063

National Oceanic and Atmospheric Administration [NOAA] (1985). Climates of the States, Vol. 1. Detroit: Gale Research Company.

National Oceanic and Atmospheric Administration [NOAA] (2018). Data Tools: 1981-2010 Normals. Available at https://www.ncdc.noaa.gov/cdo-web/ datatools/normals

Nelson, R. E., and Jordon, R. H. (1988). A postglacial pollen record from western Kodiak Island, Alaska. Arctic 41, 59-63. doi: 10.14430/arctic1693

Nichols, J., Isles, P. D. F., and Peteet, D. M. (2014a). A novel framework for quantifying past methane recycling by Sphagnum-methanotroph symbiosis using carbon and hydrogen isotope ratios of leaf wax biomarkers. Geochem. Geophys. Geosyst 15, 1827-1836. doi: 10.1002/2014GC005242

Nichols, J., Peteet, D. M., Moy, C. M., Castaneda, I. S., McGeachy, A., and Perez, M. (2014b). Impacts of climate and vegetation change on carbon accumulation in a south-central Alaskan peatland assessed with novel organic geochemical techniques. Holocene 24, 1146-1155. doi: 10.1177/0959683614540729

Nichols, J., Walcott, M., Bradley, R., Pilcher, J., and Huang, Y. (2009). Quantitative assessment of precipitation seasonality and summer surface wetness using ombrotrophic sediments from an Arctic Norwegian peatland. Quatern. Res. 72, 443-451. doi: 10.1016/j.yqres.2009.07.007

Noguchi, M., Fujiki, T., Okuno, M., Gualtieri, L., Hatfield, V., Sarata, B., et al. (2018). Vegetation changes around Haven Lake, Adak Island, Aleutians, Alaska, determined from pollen analysis. Radiocarbon 60, 1483-1492. doi: 10.1017/ RDC. 2018.103
Peteet, D. M. (1986). Vegetational history of the malaspina glacier district, alaska. Quatern. Res. 25, 100-120. doi: 10.1016/0033-5894(86)90047-5

Peteet, D. M. (1991). Postglacial history of lodgepole pine near Yakutat, Alaska. Can. J. Bot. 69, 786-796. doi: 10.1139/b91-102

Peteet, D. M., and Mann, D. H. (1994). Late-glacial vegetational, tephra, and climatic history of southwestern Kodiak Island, Alaska. Ecoscience 1, 255-267. doi: 10.1080/11956860.1994.11682250

Peteet, D. M., Nichols, J., Moy, C., McGeachy, A., and Perez, M. (2016). Recent and Holocene climate change controls on vegetation and carbon accumulation in Alaskan coastal muskegs. Quatern. Sci. Rev. 131, 168-178. doi: 10.1016/j. quascirev.2015.10.032

Sabin, A. L., and Pisias, N. G. (1996). Sea surface temperature changes in the northeastern Pacific Ocean during the last 20,000 years and their relationship to climate change in northwestern North America. Quatern. Res. 46, 48-61. doi: 10.1006/qres.1996.0043

Sachse, D., Sachse, D., Billault, I., Bowen, G. J., Chikaraishi, Y., Dawson, T. E., et al. (2012). Molecular paleohydrology: interpreting the hydrogenisotopic composition of lipid biomarkers from photosynthesizing organisms. Annu. Rev. Earth Planet. Sci. 40, 221-249. doi: 10.1146/annurev-earth-042711105535

Stuiver, M., Reimer, P. J., and Reimer, R. W. (2019). CALIB 7.1 [WWW Program]. Available at: http://calib.org

Wright, H. E. Jr., Mann, D. H., and Glaser, P. H. (1984). Piston corers for peat and lake sediments. Ecology 65, 657-659. doi: 10.2307/1941430

Conflict of Interest Statement: The authors declare that the research was conducted in the absence of any commercial or financial relationships that could be construed as a potential conflict of interest.

Copyright $@ 2019$ Peteet, Nichols and Mann. This is an open-access article distributed under the terms of the Creative Commons Attribution License (CC BY). The use, distribution or reproduction in other forums is permitted, provided the original author(s) and the copyright owner(s) are credited and that the original publication in this journal is cited, in accordance with accepted academic practice. No use, distribution or reproduction is permitted which does not comply with these terms. 